\title{
A Study on Customer Satisfaction of Old Generation and New Generation Private Sector Banks With Reference to Coimbatore City
}

\author{
D. Kalpana', R. Chandrasekaran ${ }^{2}$ \\ ${ }^{1}$ Professor in Management, Hindusthan College of Arts and Science, Coimbatore, Tamilnadu, India \\ ${ }^{2}$ Ph.D Scholar, Hindusthan College of Arts and Science, Coimbatore, Tamilnadu, India
}

\begin{abstract}
Banking sector performs three primary functions in economy, the operation of the payment system, the mobilization of savings and the allocation of saving to investment products. Banking industry has been changed after reforms process. The Government has taken this sector in a basic priority and this service sector has been changed according to the need of present days. Banking sector reforms in India strive to increase efficiency and profitability of the banking institutions as well as to bring the existing banking institutions face to face with global competition in globalization process. Different types of banks differ from each other in terms of operations, efficiency, productivity, profitability and credit efficiency. Indian banking sector is an important constituent of the Indian financial system. The banking sector plays a vital role through promoting business in urban as well as rural area in recent years. Without a sound and effective banking system, India cannot be considered as a healthy economy.
\end{abstract}

Keywords: ANOVA Analysis of Variances

\section{Introduction of Study}

Banking system occupies an important place in a nation's economy. A banking institution is indispensable in a modern society. It plays a pivotal role in the economic development of any country and forms the core of the money market. A Bank is an institution that provides financial services particularly taking deposits and extending credit. Currently the term bank is generally understood as an institution that holds a banking license. Under most jurisdictions, a banking license is a prerequisite for a financial institution that wants to provide banking services, such as taking deposits from the general public. A non-banking financial company is an institution that provides banking services without meeting the legal definition of a bank such as holding a banking license. Banking licenses are granted by bank regulatory authorities and provide rights to conduct the most fundamental banking services such as accepting deposits and making loans. There are also financial institutions that provide certain banking services without meeting the legal definition of a bank, a so-called non-banking financial company. Banks have a long history, and have influenced economies and politics for centuries.

\section{Statement of the Problem}

The public sector banks will bear the brunt of changes and the process won't be pretty. Over the last few years RBI brought more rules and regulations. Some public sector banks are still performing well. In these circumstances, private sector banks also occupy an important role in the nation's economy. Now a day's private sector banks are performing well in technology and other fields wise aggressively than public sector banks. So the good performance of private sector banks will be needed for our country's economy. Here, private sector banks are taken as two, i.e., old and new; Hence, it is very worth full study and how the old and new private sector banks are performing in this situation and also this study is to establish the performance of sect oral analysis and act as key information to the investors and shareholders for their further investment, and make analysis for efficiency of management in utilization of assets for effective functioning of private banks.

\subsection{Objectives of the Study}

- To determine the major problems faced by the customers of Old and New Generation Private Sector Commercial Banks.

- To know the level of customer satisfaction towards services of Old and New Generation Private Sector Commercial Banks in Coimbatore City.

- To provide the appropriate suggestions for getting the improvement in the existing performance

\subsection{Research Methodology}

Introduction It is a systematic and scientific method of finding solutions to a problem. "Research is a process of steps used to collect and analyze information to increase our understanding of a topic or issue" -by Creswell.

\section{A) Primary Data}

Primary data have been collected from selected respondents through questionnaire and scheduling methods.

\section{Sample Size}

The sample size is determined as 380.The population is unknown so the sample size is determined with the help of confidence interval and confidence level calculation model. Convenient sampling method was adopted to draw sample respondents. Through the aim was to select 380 customers, due to non- availability of respondents and non- response from some of the customers the researcher could not contact 20 respondents. Finally, the size of the sample was reduced 


\section{International Journal of Science and Research (IJSR) \\ ISSN (Online): 2319-7064}

Index Copernicus Value (2013): 6.14 | Impact Factor (2015): 6.391

to 360 , so it was decided to have a sample of 40 customers from each selected bank.

\section{Hypothesis of the Study}

H0: There is no significant difference in the mean scores obtained by the two bank groups, OGPB and NGPB relating to the Special features preferred by the respondents

H0: There is no significant difference in the mean scores obtained by the two bank groups, OGPB and NGPB relating to the problems faced by the respondents

\subsection{Analysis and Interpretation}

\section{Demographic Profile and Customer Satisfaction}

For studying the level of satisfaction among customers of old and new generation private sector banks, nine banks were selected. A total of 360 samples were selected by giving equal representation to all banks. Out of the 360 respondents, 40 respondents for each bank from the old and new generation private sector banks

Table 1: Types of bank and Gender of the respondents

\begin{tabular}{|c|c|c|c|c|}
\hline \multirow{2}{*}{ Types of banks } & & \multicolumn{2}{|c|}{ Gender } & \multirow{2}{*}{ Total } \\
\hline & & $\begin{array}{l}\text { Male } \\
\end{array}$ & Female & \\
\hline \multirow{2}{*}{ Federal Bank } & Count & 32 & 8 & 40 \\
\hline & Percentage & $8.9 \%$ & $2.2 \%$ & $11.1 \%$ \\
\hline \multirow{2}{*}{$\mathbf{J}$ and $\mathrm{K}$ Bank } & Count & 24 & 16 & 40 \\
\hline & Percentage & $6.7 \%$ & $4.4 \%$ & $11.1 \%$ \\
\hline \multirow{2}{*}{ KVB } & \begin{tabular}{|l|} 
Count \\
\end{tabular} & 28 & 12 & 40 \\
\hline & Percentage & $7.8 \%$ & $3.3 \%$ & $11.1 \%$ \\
\hline \multirow{2}{*}{ SIB } & Count & 34 & 6 & 40 \\
\hline & Percentage & $9.1 \%$ & $2 \%$ & $11.1 \%$ \\
\hline \multicolumn{2}{|c|}{ OGPB Total } & $118(73.7 \%)$ & $42(26.3 \%)$ & $160(100 \%$ \\
\hline \multirow{2}{*}{ ICICI Bank } & Count & 10 & 30 & 40 \\
\hline & Percentage & $3.1 \%$ & $8 \%$ & $11.1 \%$ \\
\hline \multirow{2}{*}{ HDFC Bank } & \begin{tabular}{|l|} 
Count \\
\end{tabular} & 28 & 12 & 40 \\
\hline & Percentage & $7.8 \%$ & $3.3 \%$ & $11.1 \%$ \\
\hline \multirow{2}{*}{ AXIS Bank } & Count & 28 & 12 & 40 \\
\hline & Percentage & $7.8 \%$ & $3.3 \%$ & $11.1 \%$ \\
\hline \multirow{2}{*}{ YES Bank } & \begin{tabular}{|l|} 
Count \\
\end{tabular} & 30 & 10 & 40 \\
\hline & Percentage & $8 \%$ & $3.1 \%$ & $11.1 \%$ \\
\hline \multirow{2}{*}{ KM Bank } & \begin{tabular}{|l|} 
Count \\
\end{tabular} & 36 & 4 & 40 \\
\hline & Percentage & $9.9 \%$ & $1.2 \%$ & $11.1 \%$ \\
\hline \multicolumn{2}{|c|}{ NGPB Total } & $132(66.0 \%)$ & $68(34.0)$ & $200(100 \%$ \\
\hline \multirow{2}{*}{\multicolumn{2}{|c|}{ Total }} & \begin{tabular}{|l|}
250 \\
\end{tabular} & 110 & 360 \\
\hline & & $69.4 \%$ & $30.6 \%$ & $100.0 \%$ \\
\hline
\end{tabular}

Source: Primary data
Among the 360 respondents, 250 (69.4\%) are male customers and 110(30.6\%) are females. Considering each bank separately, the majority of the respondents are males. Male customers give preference to the OGPB groups, whereas the majority of the female customers do their banking business with NGPB.

Table 2: Chi-Square Tests- Type of bank and Gender of respondents

\begin{tabular}{|c|c|c|c|}
\hline & Value & $D f$ & Asymp. Sig. (2-sided) \\
\hline Pearson Chi-Square & $9.124^{\mathrm{a}}$ & 8 & .032 \\
Source: Data Analysis
\end{tabular}

The Pearson chi-square value 9.124 with $\mathrm{df} 8$ and $\mathrm{P}$ value 0.032 it shows that the $\mathrm{P}$ value is less than 0.05 . There is high degree of association between type of bank and gender of the respondents

\section{Preference of bank group based on educational qualification}

\begin{tabular}{|c|c|c|}
\hline S.No & Educational Qualification & Preferred Bank \\
\hline 1 & Illiterate & NGPB \\
\hline 2 & School level & NGPB \&OGPB \\
\hline 3 & Graduation & NGPB \\
\hline 4 & Professional & NGPB \\
\hline
\end{tabular}

Among the illiterate group, the majority of the respondents prefer NGPB, those qualified school level prefer both and graduate and professional respondents prefer NGPB only 


\section{International Journal of Science and Research (IJSR) \\ ISSN (Online): 2319-7064}

Index Copernicus Value (2013): 6.14 | Impact Factor (2015): 6.391

Table 3: Types of bank and Reasons for selecting the bank of the respondents

\begin{tabular}{|c|c|c|c|c|c|c|c|c|}
\hline \multirow{2}{*}{$\begin{array}{c}\text { Types of } \\
\text { banks }\end{array}$} & & \multicolumn{6}{|c|}{ Reasons for selecting the bank of the respondents } & \multirow[b]{2}{*}{ Total } \\
\hline & & $\begin{array}{l}\text { Near to } \\
\text { home }\end{array}$ & Near to Office & Job necessity & Better service & $\begin{array}{l}\text { High interest } \\
\text { rate }\end{array}$ & $\begin{array}{l}\text { Any other } \\
\text { reason }\end{array}$ & \\
\hline \multirow{2}{*}{ Federal Bank } & Count & 13 & 5 & 12 & 10 & 0 & 0 & 40 \\
\hline & $\%$ & $3.6 \%$ & $1.4 \%$ & $3.3 \%$ & $2.8 \%$ & $0.0 \%$ & $0.0 \%$ & $11.1 \%$ \\
\hline \multirow{2}{*}{$\mathbf{J}$ and $\mathrm{K}$ Bank } & Count & 12 & 3 & 14 & 11 & 0 & 0 & 40 \\
\hline & $\%$ & $3.3 \%$ & $0.8 \%$ & $3.9 \%$ & $3.1 \%$ & $0.0 \%$ & $0.0 \%$ & $11.1 \%$ \\
\hline \multirow{2}{*}{ KVB } & Count & 11 & 4 & 16 & 7 & 2 & 0 & 40 \\
\hline & $\%$ & $3.1 \%$ & $1.1 \%$ & $4.4 \%$ & $1.9 \%$ & $0.6 \%$ & $0.0 \%$ & $11.1 \%$ \\
\hline \multirow{2}{*}{ SIB } & Count & 10 & 7 & 12 & 11 & 0 & 0 & 40 \\
\hline & $\%$ & $2.8 \%$ & $1.9 \%$ & $3.3 \%$ & $3.1 \%$ & $0.0 \%$ & $0.0 \%$ & $11.1 \%$ \\
\hline \multicolumn{2}{|c|}{ OGPB Total \% } & 12.8 & 3.3 & 14.9 & 10.9 & 0.6 & $\mathbf{0}$ & \\
\hline \multirow{2}{*}{ ICICI Bank } & Count & 15 & 1 & 12 & 12 & 0 & 0 & 40 \\
\hline & $\%$ & $4.2 \%$ & $0.3 \%$ & $3.3 \%$ & $3.3 \%$ & $0.0 \%$ & $0.0 \%$ & $11.1 \%$ \\
\hline \multirow{2}{*}{ HDFC Bank } & Count & 13 & 2 & 15 & 8 & 2 & 0 & 40 \\
\hline & $\%$ & $3.6 \%$ & $0.6 \%$ & $4.2 \%$ & $2.2 \%$ & $0.6 \%$ & $0.0 \%$ & $11.1 \%$ \\
\hline \multirow{2}{*}{ AXIS Bank } & Count & 10 & 5 & 17 & 8 & 0 & 0 & 40 \\
\hline & $\%$ & $2.8 \%$ & $1.4 \%$ & $4.7 \%$ & $2.2 \%$ & $0.0 \%$ & $0.0 \%$ & $11.1 \%$ \\
\hline \multirow{2}{*}{ YES Bank } & Count & 9 & 7 & 16 & 7 & 0 & 1 & 40 \\
\hline & $\% \mathrm{e}$ & $2.5 \%$ & $1.9 \%$ & $4.4 \%$ & $1.9 \%$ & $0.0 \%$ & $0.3 \%$ & $11.1 \%$ \\
\hline \multirow{2}{*}{ KM Bank } & Count & 10 & 0 & 19 & 11 & 0 & 0 & 40 \\
\hline & $\%$ & $2.8 \%$ & $0.0 \%$ & $5.3 \%$ & $3.1 \%$ & $0.0 \%$ & $0.0 \%$ & $11.1 \%$ \\
\hline \multicolumn{2}{|c|}{ NGPB Total \% } & 15.9 & 6.1 & 21.9 & 12.7 & 0.6 & 0.3 & 200 \\
\hline \multirow{2}{*}{\multicolumn{2}{|c|}{ Total }} & 103 & 34 & 133 & 85 & 4 & 1 & 360 \\
\hline & & $28.6 \%$ & $9.4 \%$ & $36.9 \%$ & $23.6 \%$ & $1.1 \%$ & $0.3 \%$ & $100.0 \%$ \\
\hline
\end{tabular}

Source: Primary data

From the responses of 360 customers, it is observed that they give prime importance for maintaining Account is job

From the above table, it is clear that the majority of the respondents opening Account for the purpose of withdraw their salary (job necessity).

Table 4: Chi-Square Tests- Type of bank and Reasons for selecting the bank of the respondents

\begin{tabular}{|l|l|l|l|}
\hline & Value & Df & Asymp. Sig. (2-sided) \\
\hline Pearson Chi-Square & $44.312^{\mathrm{a}}$ & 40 & .295 \\
\hline
\end{tabular}
Source: Data Analysis

The Pearson chi-square value 44.312 with df 40 and $\mathrm{P}$ value 0.295 it shows that the $\mathrm{P}$ value is greater than 0.05 .There is no association between type of bank and reason for selecting their favourite bank of respondents.

\section{Henry Garrett Ranking}

Table 5: Respondents' opinion about their banks' Special features

\begin{tabular}{|c|c|c|c|c|c|c|c|}
\hline \multirow[t]{2}{*}{ S. No } & \multirow[t]{2}{*}{ Special features } & \multicolumn{3}{|c|}{ OGPB } & \multicolumn{3}{|c|}{ NGPB } \\
\hline & & Score & Mean & Rank & Score & Mean & Rank \\
\hline 1 & Locker facility & 7051 & 19.59 & IX & 9662 & 26.84 & $\mathrm{X}$ \\
\hline 2 & ATM facility & 7771 & 21.59 & VII & 12217 & 33.90 & $\mathrm{~V}$ \\
\hline 3 & Cash deposit machine & 7633 & 21.20 & VIII & 13204 & 36.71 & II \\
\hline 4 & Agency services & 7008 & 19.47 & $\mathrm{X}$ & 11260 & 31.28 & VII \\
\hline 5 & Debit / Credit card facility & 8617 & 23.94 & IV & 11985 & 33.29 & VI \\
\hline 6 & Internet banking & 8987 & 24.96 & II & 13344 & 37.07 & I \\
\hline 7 & Loan processing & 9064 & 25.18 & I & 13183 & 36.62 & III \\
\hline 8 & Customer care & 8129 & 22.58 & VI & 9986 & 27.74 & IX \\
\hline 9 & High interest & 8475 & 23.54 & $\mathrm{~V}$ & 10549 & 29.30 & VIII \\
\hline 10 & Location advantage & 8977 & 24.94 & III & 12402 & 34.45 & IV \\
\hline
\end{tabular}

Source: Data Analysis necessity while selecting their favourite bank, followed by better service, it constituting 85 (23.6\%) of the respondents.

This method is used to find out the most important factor from the given factors based on their ranks. As per this method, respondents have been asked to assign the rank for all the factors and out of such ranking have been converted into score value with the help of the following Formula:

Percent position $=100\left(\mathrm{R}_{\mathrm{ij}}-0.05\right) / \mathrm{N}_{\mathrm{j}}$

$R_{i j}$ - Rank given for the $i^{\text {th }}$ factor by the $j^{\text {th }}$ respondents.

$\mathrm{N}_{\mathrm{j}}$ - Number of factors ranked by the $\mathrm{j}^{\text {th }}$ respondents.

The percentage position of each rank thus obtained is converted into scores by referring to the table given by Hendry Garret. Then for each factor the scores of individual respondents are added together and divided by the total number of respondents for whom the scores were added. Ranks are given on the basis of the mean score values and most important factors are identified 


\section{International Journal of Science and Research (IJSR) \\ ISSN (Online): 2319-7064 \\ Index Copernicus Value (2013): 6.14 | Impact Factor (2015): 6.391}

The above table disclosed the special features relating to the bank group, in that "Loan processing" was ranked first in OGPB with the score of 9064, it was followed by "Internet banking" with the score of 8987 . The third rank was obtained by "Location advantage" with the score of 8977 . Where as in NGPB the first rank obtained by "Internet banking" with score of 13344, it is followed by "Cash deposit procedure" with score of 13204, the third rank obtained by " loan processing" with score of 13183.
From the above analysis it is found that "Loan processing" is the special feature of OGPB and Internet banking is the special feature of NGPB.

\section{Hypothesis 1}

H0: There is no significant difference in the mean scores obtained by the two bank groups, OGPB and NGPB relating to the Special features preferred by the respondents

Table 6: Special features- ANOVA showing difference between bank groups

\begin{tabular}{|l|l|r|r|r|r|r|r|}
\hline \multirow{4}{*}{ Special features } & Source of Variation & \multicolumn{1}{|c|}{ SS } & \multicolumn{1}{c|}{ Df } & \multicolumn{1}{c|}{ MS } & $F$ & $P$-value & F crit \\
\cline { 2 - 8 } & Between Groups & 272.91 & 1.00 & 272.91 & 39.31 & 0.00 & 4.41 \\
\cline { 2 - 8 } & Within Groups & 124.97 & 18.00 & 6.94 & & & \\
\cline { 2 - 8 } & Total & 397.88 & 19.00 & & & & \\
\hline
\end{tabular}

Source: Data Analysis

From the above table, the F value is greater than F critical value. So the Null Hypothesis is rejected, which means there is significance of mean value of two groups.

Table 7: Respondents' opinion about the problems faced towards their banks

\begin{tabular}{|c|c|c|c|c|c|c|c|}
\hline \multirow{2}{*}{ S.NO } & \multirow{2}{*}{ Problems faced by the Respondents } & \multicolumn{3}{|c|}{ OGPB } & \multicolumn{3}{|c|}{ NGPB } \\
\cline { 3 - 8 } & & Score & Mean & Rank & Score & Mean & Rank \\
\hline 1 & Delay in processing loan & 8226 & 22.85 & VIII & 9666 & 26.85 & X \\
\hline 2 & More formalities & 9206 & 25.57 & I & 12023 & 33.40 & III \\
\hline 3 & Short period of repayment & 6921 & 19.23 & X & 10334 & 28.71 & VIII \\
\hline 4 & Hidden cost & 7764 & 21.57 & IX & 9684 & 26.90 & IX \\
\hline 5 & More processing charges & 8347 & 23.19 & VI & 10969 & 30.47 & V \\
\hline 6 & Low rate of interest on deposit & 8296 & 23.04 & VII & 12657 & 35.16 & I \\
\hline 7 & High rate of interest on loan & 8637 & 23.99 & IV & 12642 & 35.12 & II \\
\hline 8 & Difficulty to fill the application & 9188 & 25.52 & II & 10414 & 28.93 & VII \\
\hline 9 & Buren of pre payment penalty & 8440 & 23.44 & V & 10522 & 29.23 & VI \\
\hline 10 & Frequent failure of ATM & 9147 & 25.41 & III & 11850 & 32.92 & IV \\
\hline
\end{tabular}

Source: Data Analysis

The above table disclosed the problems faced by the respondents while transaction with their banks, in that "More formalities" was ranked first in OGPB with the score of 9206, it was followed by "Difficulty to fill the application" with the score of 9188. The third rank was obtained by "Frequent failure of ATM" with the score of 9147. Where as in NGPB the first rank obtained by "Low rate of interest on deposit" with score of 12657, it is followed by"High rate of interest on loan" with score of 12642, the third rank obtained by "More formalities" with score of 12023. From the above analysis it is found that "More formalities" \& Difficulty in fill the application are main problems of OGPB where as Interest is the main problem of NGPB.

\section{Hypothesis 2}

H0: There is no significant difference in the mean scores obtained by the two bank groups, OGPB and NGPB relating to the problems faced by the respondents.

Table 8: Problems faced- ANOVA showing difference between bank groups

Source: Data Analysis

\begin{tabular}{|c|c|c|c|c|c|c|c|}
\hline \multirow{3}{*}{$\begin{array}{c}\text { Problems faced by } \\
\text { the respondents }\end{array}$} & Source of Variation & $S S$ & $d f$ & $M S$ & $F$ & $P$-value & $F$ crit \\
\cline { 2 - 8 } & Between Groups & 272.75 & 1.00 & 272.75 & 39.28 & 0.00 & 4.41 \\
\cline { 2 - 8 } & Within Groups & 125.00 & 18.00 & 6.94 & & & \\
\cline { 2 - 8 } & Total & 397.75 & 19.00 & & & & \\
\hline
\end{tabular}

From the above table, the $\mathrm{F}$ value is greater than $\mathrm{F}$ critical value. So the Null Hypothesis is rejected, which means there is significance of mean value of two groups.

\section{Findings}

Majority of respondents (69.4\%) are male customers and they all are gives preference to the OGPB groups. There is high degree of association between type of bank and gender of the respondents
It is observed that the majority of respondents (36.9\%) give prime importance for maintaining Account is job necessity while selecting their favourite bank. There is no association between type of bank and reason for selecting their favourite bank of respondents.

The researcher found "Loan processing" was ranked first in OGPB as special feature with the score of 9064 and in NGPB the first rank obtained by "Internet banking" with score of 13344. There is significance of mean value of two groups. 
The researcher found as the problem faced by respondents while transaction was "More formalities", it was ranked first in OGPB with the score of 9206 and in NGPB the first rank obtained by "Low rate of interest on deposit" with score of 12657. There is significance of mean value of two groups.

\section{Conclusion}

The research was aimed at studying the performance level and satisfaction of old vs. new generation private sector commercial banks in India. Private sector banks play an important role in the development of Indian economy. After introduction of New Generation private sector commercial banks, the banking industry underwent major changes. The Indian banking industry was dominated by public sector banks. But now the situation has changed private sector banks with use of technology and professional management has gained a reasonable position in the banking industry. Banking consistitutes an important link in several socioeconomic activities. Therefore, the banking industry must be on a sound financial position. While in India, there is stress on the social responsibility of banks, the significance of liquidity and profitability is not to be neglected. The financial viability of the banking system is certainly essential; not only to instill public confidence but also to make banks capable of discharging their social responsibilities. Further, the rate of profit is taken as an indicator of the operational efficiency of banks. From the performance analysis, it is clearly seen that in selected private sector banks, the new generation private sector banks in India provide large number of services to their customers and the general public for several years. These banks update their services and adopt the modern technology in providing services to their customers. Private sector banks today are well able to modernize the services to the new generation private sector bank customer. But when it comes to serving rural customers, they need to have different approach in conducting \& persuading the rural customers. It may be for the reasons such as educational \& social backwardness and their living style that play prominent role in their choice and preference. The behavior of rural customers need to be studied in detail and may be compared with the behavior of urban customers. In order to short out the appropriate strategy for meeting the needs and satisfying the rural customers. The service quality aspect of private sector banks for serving rural customers need to be viewed separately and focused their attention with greater interest. Thus, the success of public sector banks mainly depend on how will they understand the rural customers and how will they adopt strategies to serve them better.

\section{References}

[1] Antonina Davydenko, "Determinants of bank profitability in Ukraine, Undergraduate economic" Review, Vol.7 [2011], Issue.1, Art.2, PP 1-47.

[2] Badola, B.S and Richa Verma, "Determinants of Profitability of Banks In India A Multivariate Analysis", Delhi Business Review X Vol.7, No.2, July - December 2006. PP. $79-88$.

[3] Parimal Vyas "Management of customer satisfaction: A study of banking services", Business perspectives, Vol 4, Jan-Jul 2002, PP 73-88. 